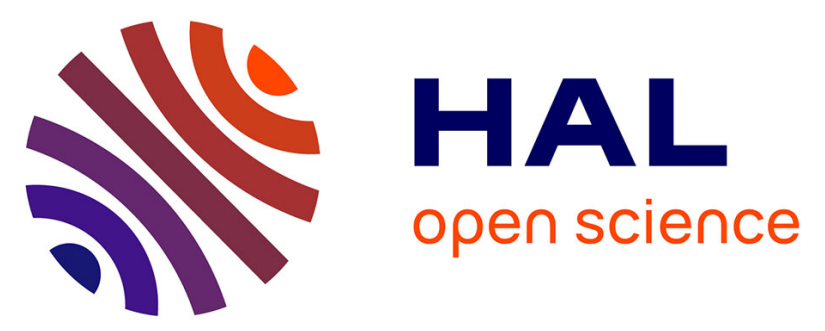

\title{
Food puncture resistance, ingesting behavior and the curvature of upper second molars in Old World and New World monkeys
}

\author{
Ghislain Thiery, Franck Guy, Vincent Lazzari
}

\section{- To cite this version:}

Ghislain Thiery, Franck Guy, Vincent Lazzari. Food puncture resistance, ingesting behavior and the curvature of upper second molars in Old World and New World monkeys. Computer Methods in Biomechanics and Biomedical Engineering, 2019, 44th Congress of the Société de Biomécanique, 22 (Sup1), pp.S392-S394. 10.1080/10255842.2020.1714956 . hal-02408465

\section{HAL Id: hal-02408465 https://hal.science/hal-02408465}

Submitted on 15 Jun 2020

HAL is a multi-disciplinary open access archive for the deposit and dissemination of scientific research documents, whether they are published or not. The documents may come from teaching and research institutions in France or abroad, or from public or private research centers.
L'archive ouverte pluridisciplinaire HAL, est destinée au dépôt et à la diffusion de documents scientifiques de niveau recherche, publiés ou non, émanant des établissements d'enseignement et de recherche français ou étrangers, des laboratoires publics ou privés. 


\section{Food puncture resistance, ingesting behavior and the curvature of upper second molars in Old World and New World monkeys}

\section{G. Thiery, F. Guy \& V. Lazzari}

To cite this article: G. Thiery, F. Guy \& V. Lazzari (2019) Food puncture resistance, ingesting behavior and the curvature of upper second molars in Old World and New World monkeys, Computer Methods in Biomechanics and Biomedical Engineering, 22:sup1, S392-S394, DOI: 10.1080/10255842.2020.1714956

To link to this article: https://doi.org/10.1080/10255842.2020.1714956 (c) 2020 The Author(s). Published by Informa
UK Limited, trading as Taylor \& Francis Group

Published online: 22 May 2020.

Submit your article to this journal

Щ Article views: 26

Q View related articles $₫$

View Crossmark data $\nearrow$ 


\section{Food puncture resistance, ingesting behavior and the curvature of upper second molars in Old World and New World monkeys}

\author{
G. Thiery, F. Guy and V. Lazzari \\ PALEVOPRIM UMR CNRS 7262, University of Poitiers, Poitiers \\ Cedex, France
}

\section{Introduction}

For paleontologists, teeth are often the only way to infer the diet of an extinct mammal. Through repeated contacts over a lifetime, food may induce tooth fracture, exerting a natural selection on tooth form. Dental form is therefore expected to inform on tooth function (i.e. the food it processes the best without breaking).

Like other animals, primates eat many kinds of food items, which are usually separated into traditional, 'organ-based' categories: leaves, fruits, insects, etc. It follows that animals eating leaves are folivorous, animals eating fruit are frugivorous, and so on. Still, most primates do not limit their diet to one traditional category. Besides, traditional categories group a wide range of food items with sometimes contrasting physical properties. In other words, two 'frugivorous' species might be confronted to different mechanical - and therefore dental - challenges. To date however, most studies investigating dental form and function have been doing so using traditional categories. The present work compares instead dental sharpness, measured as the average mean curvature, to the puncture resistance of challenging plant foods consumed by primates.

\section{Methods}

\subsection{Materials}

We collected 20 skulls from six extant genera of Old World and New World monkeys: Ateles spp. $(\mathrm{N}=3)$, Cercocebus spp. $(\mathrm{N}=2)$, Cercopithecus spp. $(\mathrm{N}=8)$, Chiropotes satanas $(\mathrm{N}=1)$, Lophocebus albigena $(\mathrm{N}=4)$ and Pithecia pithecia $(\mathrm{N}=2)$. To remove the influence of dental wear, we only selected subadult specimens which showed minimal to no apical wear on second upper molars.

\subsection{Dental models}

Upper second molars were scanned using high resolution Xray computed microtomography (EasyTom, Centre de Microtomographie of Poitiers). Isovoxel resolution spanned from 10 to $30 \mu \mathrm{m}$. Following Guy et al. (2015), we segmented the enamel cap using Avizo Fire, then extracted a polygonal model of the tooth outer surface, retesselated the models to $\sim 50.000$ polygons and oriented them using Geomagic Studio.

\subsection{Measure of dental curvature}

For each polygon of our dental models, we computed mean curvature in $\mathrm{R}$ 3.3.0 using the vcgCurve function of the Rvcg package (Schlager 2017). To mitigate the effects of allometry, we standardized polygon curvature by the average mean curvature of a toothsized hemisphere:

$$
\text { StandardCurv } v_{\text {poygron }}=\frac{\text { polygon }}{2,4481 \times \sqrt{3 \text { Darea }_{\text {model }}}}
$$

where $3 \mathrm{Darea}_{\text {model }}$ is the tridimensional surface area of the dental model. For each model, sharpness was computed as the third quartile of all curvature values.

\subsection{Food physical properties}

Physical properties of plant foods were collected from the literature (Figure 1). Testing procedures were not always compatible, so we restricted this work to puncture resistance measured as the pressure in $\mathrm{kg} \cdot \mathrm{mm}-2$ needed to puncture the food with the needle of a portable agricultural fruit tester (Model 719-40MRP, Chatillon \& Sons). For each species, the puncture resistance from which food could be considered challenging while not anecdotally consumed was estimated as the third quartile of all puncture resistance scores.

\section{Results and discussion}

As expected, the frequency of low puncture resistance plants was much higher than the frequency of challenging, high puncture resistance plants (Figure 1(a, b)). This is likely related to the avoidance of challenging plants when more palatable foods are available. Regarding dental form, sharpness was moderately 


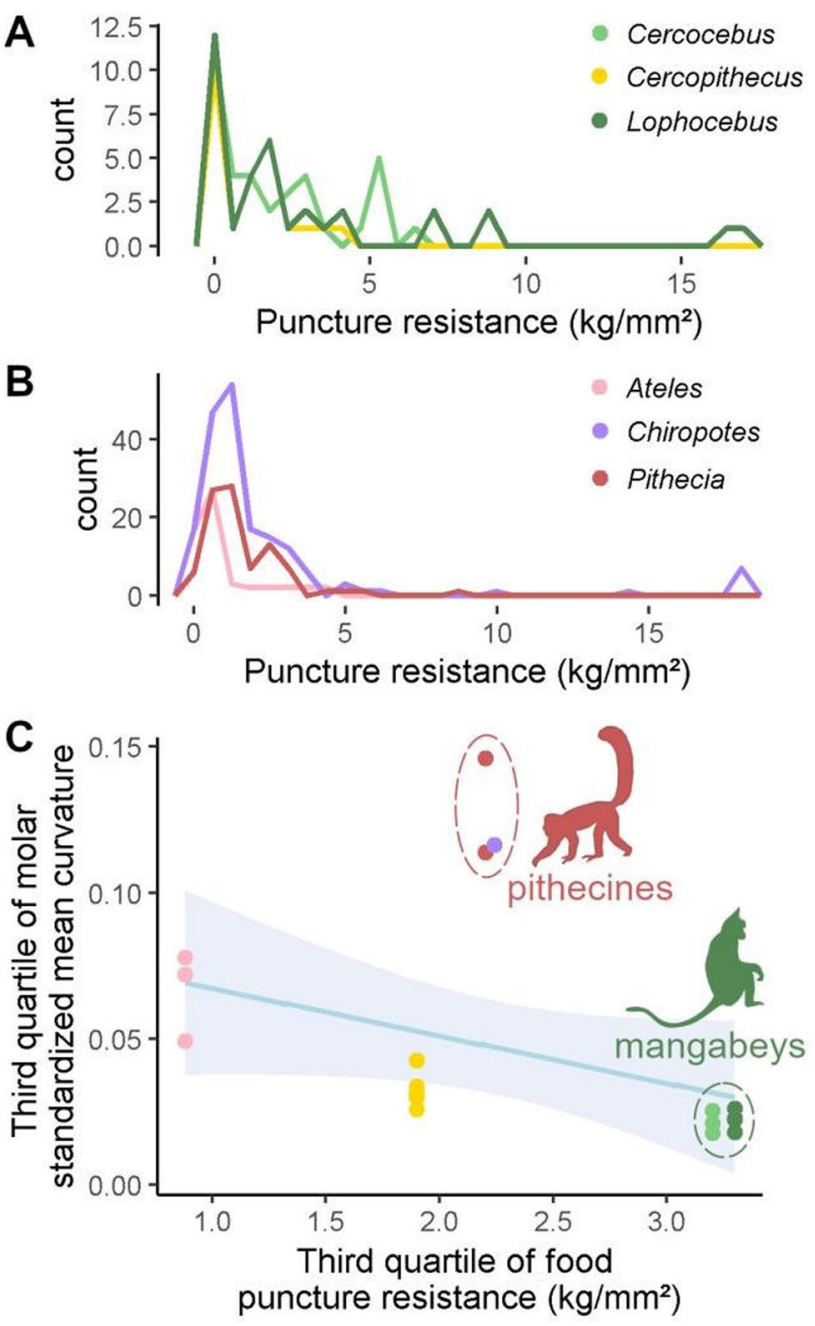

Figure 1. Puncture resistance of plants consumed by Old World monkeys (A, adapted from Lambert et al. 2004; Wieczkowski 2009) and New World monkeys (B, adapted from Norconk and Veres 2011) versus the third quartile of their molar curvature (C). Regression line showed with a 95\% confidence interval.

anticorrelated to challenging food puncture resistance (Spearman's rank correlation rho $=-0.60, p$-value $<$ 0.01 ). Mangabeys (in green, Figure 1(c)) have the lowest molar sharpness. The mangabeys are seed predators and use their thick-enameled molars to crush seed shells (Norconk et al. 2013), which may have acted as a natural limiter to dental sharpness. In contrast, pithecines have the highest molar sharpness of the sample despite being notorious seed predators. However, this discrepancy between dental form and the food it is expected to process the best can be explained by their feeding behavior. The pithecines are indeed known to ingest hard, challenging food using their robust, thick-enameled anterior teeth (incisors and canines) instead of their molars (Norconk et al. 2013).

\section{Conclusions}

With the notable exception of pithecines, molar sharpness estimated from mean curvature correlates to the puncture resistance of the staple challenging plant foods of Old World and New World monkeys (Figure 1(c)). In other words, the more punctureresistant is the food, the less sharp are the teeth adapted to its consumption. The high curvature of pithecines is attributed to the fact that they do not use their molars to pry challenging seed shells open, which likely allowed sharper molars to be selected.

This work illustrates the importance of both mechanical data, obtained from plant collected in the field, and ecological data, obtained from field observation of primates, for understanding dental form and function. Applying this method to many extant species, using a wide set of physical properties, will improve our understanding of how food actually selected dental morphology. Only then may we use dental form to accurately infer the diet of extinct mammals.

\section{Acknowledgements}

We thank the Muséum National d'Histoire Naturelle of Paris (France), the Royal Museum of Central Africa (Tervuren, Belgium) and the Senckenberg Museum of Frankfurt (Germany).

\section{Funding}

This work was supported by the Agence Nationale de la Recherche (ANR-09-BLAN-0238 and ANR-17-CE02-001001), the Ministère de l'Enseignement Supérieur, de la Recherche et de l'Innovation, the région Poitou-Charentes (Conventions Région \#07/RPC-R-100 and \#12/RPC-013) and the International Primatological Society.

\section{References}

Guy F, Lazzari V, Gilissen E, Thiery G. 2015. To what extent is primate second molar enamel occlusal morphology shaped by the enamel-dentine junction? Plos One. 10(9):e0138802.

Lambert JE, Chapman CA, Wrangham RW, ConklinBrittain NL. 2004. Hardness of cercopithecine foods: Implications for the critical function of enamel thickness in exploiting fallback foods. Am J Phys Anthropol. 125(4):363-368.

Norconk MA, Grafton BW, McGraw WS. 2013. Morphological and ecological adaptations to seed predation: a primate-wide perspective. In: Barnett AA, Veiga LM, Norconk MA, Ferrari SF, editors. Evolutionary biology and conservation of titis, sakis and uacaris. Cambridge: Cambridge University Press; p. 55-71. 
Norconk MA, Veres M. 2011. Physical properties of fruit and seeds ingested by primate seed predators with emphasis on sakis and bearded sakis. Anat Rec. 294(12): 2092-2111.

Schlager S. 2017. Morpho and Rvcg-shape analysis in R: Rpackages for geometric morphometrics, shape analysis and surface manipulations. In: Zheng G, Li S, Szekely G, editors. Statistical shape and deformation analysis. Cambridge, MA: Academic Press; p. 218-256.
Wieczkowski J. 2009. Brief communication: puncture and crushing resistance scores of Tana river mangabey (Cercocebus galeritus) diet items. Am J Phys Anthropol. 140(3):572-577.

KEYWORDS Comparative anatomy; diet; primates; puncture resistance; tooth sharpness

@ ghislain.thiery@ntymail.com 